J. Clin. Chem. Clin. Biochem.

Vol. 17, 1979, pp. 547-551

\title{
Enzymic Assay of Plasma Cholesterol: A Comparison of Analytical Variations Found Using the Greiner GSA II and the Technicon SMA 12/60 and SMA II
}

\author{
By Josiane Steinmetz, Edwige Panek and Evelyne Gaspart \\ Laboratoire du Centre de Médecine Préventive (Directeur: Prof. G. Siest), 2 avenue du Doyen Jacques Parisot, \\ 54500 Vandoeuvre-les-Nancy, France
}

\begin{abstract}
Laboratoire de Biochimie Pharmacologique, Facultè des Sciences Pharmaceutiques ct Biologiques, 7 rue Albert Lebrun, 54000 Nancy, France
\end{abstract}

(Received December 15, 1978/April 4, 1979)

Summary: Cholesterol was assayed on the Greiner GSA II and the Technicon SMA 12/60 and SMA II autoanalyzers, with Allain's entirely enzymic method (Allain et al. (1974), Clin. Chem. 20, 470-475). The coefficients of variation in the results over a period of one month were less than $6 \%$ with the GSA II and the SMA II, but up to $9 \%$ on the SMA 12/60. Although the accuracy of the enzymic method depends on the specificity of the cholesterol oxidase and cholesterol esterase, the results were in good agreement with those obtained by $A$ bell s method ( $A$ bell et al. (1952), J. Biol. Chem. 195, 357-366) on fresh or freeze dried human plasma. The cholesterol concentration was stable at $4^{\circ} \mathrm{C}$, or in frozen or freeze dried plasma. None of the drugs tested interfered with the enzymic assay.

Enzymatische Bestimmung von Cholesterin im Plasma: Vergleich analytischer Abweichungen, beobachtet beim Einsatz des Greiner GSA II und des Technicon SMA 12/60 sowie SMA II

Zusammenfassung: Cholesterin wurde am Greiner GSA II und den Technicon SMA 12/60 und SMA II Autoanalyzern mit der vollenzymatischen Methode von Allain et al. ((1974), Clin. Chem. 20, 470-475) bestimmt. Die Variationskoeffizienten der über einen Zeitraum von einem Monat erhaltenen Ergebnisse waren $<6 \%$ mit dem GSA II und dem SMA II, aber bis zu 9\% mit dem SMA 12/60. Obwohl die Richtigkeit der enzymatischen Methode von der Spezifität der Cholesterinoxidase und -esterase abhängt, stimmen die Ergebnisse gut mit denen überein, die mit der Methode von Abell et al. ((1952), J. Biol. Chem. 195, 357-366) an frischem oder lyophilisiertem Plasma von Menschen erhalten wurden. Die Cholesterinkonzentration war bei $4{ }^{\circ} \mathrm{C}$ oder in gefrorenem oder lyophilisiertem Plasma stabil. Keine der geprüften Pharmaka störten den enzymatischen Test.

\section{Introduction}

Enżymic methods for assaying cholesterol are based on the measurement of the hydrogen peroxide formed when cholesterol esters àre hydrolyzzed by cholesterol esterase and the cholesterol thus liberated is oxidized by cholesterol oxidase. Various colorimetric reactions have been used in these assays (1). Trinder's reaction is now the most commonly used; it was applied to cholesterol assays by Allain et al. (2) and adapted to many autoanalyzers - continuous-flow $(3,4,5)$, centrifugal $(6,7,8)$, the Vickers $(9,10,11)$, and the Greiner GSA II (12).

Here we report results obtained in our laboratory with inree apparatuses for cholesterol assay, using the method of Allain et al. One apparatus, the Greiner GSA II, uses discrete analysis, and the Technicon SMA 12/60 and
SMA II use continuous flow. Beside control for precision and linearity, the accuracy and specificity of the measurements made with the three apparatuses have been verified by comparison with those obtained by the selective chemical method of $A$ bell et al. (13). In addition, we have made tests on short-term and long-term storage (at $+4{ }^{\circ} \mathrm{C}$ and $-196^{\circ} \mathrm{C}$, respectively) of plasma cholesterol. The results are discussed with regard to the difficulties resulting from the lack of a primary cholesterol standard for enzymic assay of cholesterol.

\section{Materials and Methods}

Method of Abell et al. (13)

Cholesterol esters were saponified with alcoholic potassium hydroxide. Cholesterol was extracted with petroleum ether, then assayed by means of the Liebermann-Burchard reaction 
Tab. 1. Final reagent concentration used for enzymic cholesterol assays on three automated analyzers.

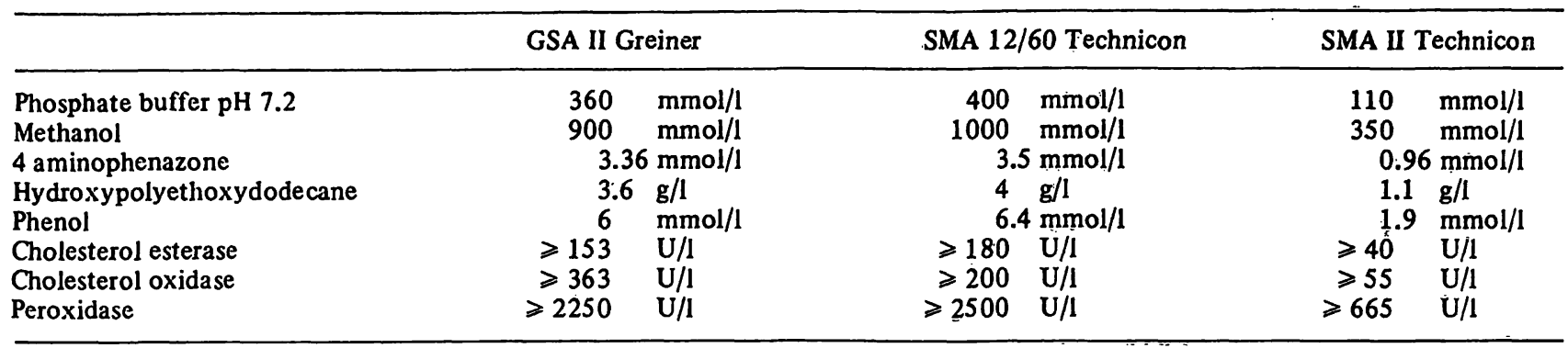

after evaporation of the solvent. The reagents were prepared in our laboratory. The calibration curve was obtained from cholesterol (product No. 26740 puriss from Fluka) dissolved in ethanol. The technique used was entirely manual, and the intensity of the coloration was read from a Beckman DB-GT spectrophotometer.

\section{Enzymic method}

Reagents

For the Greiner GSA II and the Technicon SMA 12/60, we used a reagent kit (Boehringer, ref. 148393). The final reagent concentrations are given in table 1 . The composition of reaction mixture 2, used to measure the serum blank on the Greiner GSA II, was identical to that used for the assay (mixture 1) except for the cholesterol oxidase which was omitted. The concentrations were similar in the two apparatuses. However, cholesterol oxidase activity was twice as high in the reaction mixture used in the Greiner GSA II; this mixture was prepared 12 to $15 \mathrm{~h}$ before use, in accordance with the recommendations of Van Gent et al. (14) and Borner et al. (12).

In the Technicon SMA II, the Technicon reagents were used at the final concentrations shown in table 1.

\section{Technique}

For the Greiner GSA II, the analytical procedure followed was that recommended in technical leaflet 74-3F-1/03/76 (tab. 2). A sample blank was run in parallel for each assay. The ratio of sample volume to final volume was 1 to 161 . The absorbance of the assay was read at $546 \mathrm{~nm}$ and the absorbance of the blank was subtracted from that of the assay. The corrected absorbance is reported as $A$.

Tab. 2. Experimental protocol for cholesterol assay on the GSA II Greiner.

\begin{tabular}{lccl}
\hline & $\begin{array}{l}\text { Volumes } \\
\text { Blank } \\
(\mu \mathrm{l})\end{array}$ & $\begin{array}{l}\text { Assay } \\
(\mu \mathrm{l})\end{array}$ & $\begin{array}{l}\text { Incubation } \\
\text { time } \\
(\min ; \mathrm{s})\end{array}$ \\
\hline Plasma & 10 & 10 & - \\
Distilled water & 100 & 100 & - \\
Reaction mixture 1 & - & 1500 & $8 ; 40$ \\
Reaction mixture 2 & 1500 & - & $8 ; 06$ \\
Final volume & 1610 & 1610 & $\ldots$ \\
\hline
\end{tabular}

\section{Calculation}

The molar concentration of cholesterol was calculated according to the formula:

$$
\mathrm{C}=\mathrm{A} \times \frac{1}{\epsilon} \times \frac{\mathrm{FV}}{\mathrm{SV}}
$$

where $\epsilon=$ molar absorption coefficient

$$
\begin{aligned}
& \mathrm{FV} \text { (final volume) }=1610 \mu \mathrm{l} \\
& \mathrm{SV} \text { (sample volume) }=10 \mu \mathrm{l} \\
& \frac{1}{\epsilon} \times \frac{\mathrm{FV}}{\mathrm{SV}}=\mathrm{K} \text { (the multiplication coefficient) }
\end{aligned}
$$

For the Technicon SMA 12/60, we followed the manufacturer's instructions. Unlike the Greiner GSA II, it does not require the use of a reagent blank. The ratio of sample volume to final volume was 1 to 280 . The absorbance was read at $546 \mathrm{~nm}$.

For the Technicon SMA II, the assay procedure recommended by the manufacturer was not changed.

\section{Results and Discussion}

\section{Incubation time}

We verified that the time necessary for color development at $37^{\circ} \mathrm{C}$ was 4 minutes. The incubation times were 8 min $40 \mathrm{~s}$ with the Greiner GSA II, $5 \min 20 \mathrm{~s}$ with the Technicon SMA II, and only $50 \mathrm{~s}$ with the Technicon SMA 12/60. In the continuous-flow apparatus, however, the sample is already in contact with the reagents before it enters the water-bath. The absorbance was read at the reaction plateau only with the GSA II and the SMA II.

\section{Calibration}

The calibration of an apparatus for enzymic cholesterol assay poses the particular problem that there are at present no aqueous primary solutions of cholesterol. The Greiner GSA II is calibrated by displaying a coefficient $\mathrm{K}$, which can be calculated from the molar absorption coefficient of the chromogen formed from the reaction of hydrogen peroxide with the phenol/4 aminophenazone pair.

The value for the multiplication coefficient was 46.85 when we used a solution of hydrogen peroxide. When hydrogen peroxide dilutions were replaced by human sera calibrated by $A$ bell s method, the multiplication coefficient was 38.02, which was the value used for calibration.

The SMA 12/60 and the SMA II were also calibrated with commercial titrated human sera. 
Repeatability and reproducibility

The repeatability was evaluated by duplicate assays of plasma from the patients. The coefficient of variation was less than $1.5 \%$ for the GSA II and $2.8 \%$ for the SMA $12 / 60$ and the SMA II (tab. 3).

Tab. 3. Repeatability of cholesterol assay on three automated analyzers (Results are expressed in $\mathrm{mmol} / \mathrm{l}$ ).

\begin{tabular}{llll}
\hline & $\begin{array}{c}\text { GSA II } \\
\text { Greiner }\end{array}$ & SMA 12/60 & SMA II \\
\hline Number of pairs & 30 & 64 & 41 \\
Mean and variance & & & \\
Sample 1 & 5.87 & 6.25 & 4.62 \\
& $(0.87)$ & $(0.61)$ & $(1.12)$ \\
Sample 2 & 5.89 & 6.27 & 4.59 \\
& $(0.83)$ & $(0.61)$ & $(1.15)$ \\
Coefficient of variation \% & 1.5 & 2.8 & 2.7 \\
\hline
\end{tabular}

The reproducibility was calculated from an untitrated, freeze-dried serum assayed several times a day. The results are given in table 4 . The variation coefficient was 2.3 to $6.6 \%$ (depending on the month) with the GSA II, $9 \%$ with the SMA $12 / 60$, and $5 \%$ with the SMA II. The reproducibility of $A$ bell's chemical method was $3.7 \%$ within one day and $6.8 \%$ from day to day.

\section{Linearity}

Linearity was measured from increasing dilutions of hyperlipemic plasmas and verified up to concentrations of $13 \mathrm{mmol} / \mathrm{l}$ on the GSA II and up to $10 \mathrm{mmol} / \mathrm{l}$ on the SMA II. The SMA 12/60 gave a linear response only from $3.6 \mathrm{mmol} / \mathrm{l}$ up to $10 \mathrm{mmol} / 1$.

\section{Accuracy}

The accuracy of the results was assessed by intralaboratory and interlaboratory quality controls.

\section{Intralaboratory control}

Cholesterol was assayed in fresh human plasma samples simultaneously on the three apparatuses, and according to Abell's method, which is considered the selected method. The results, compared with those obtained by the chemical method, are given in table 5 .

There is an overestimation of $3 \%$ in the results obtained with the GSA II, $6.5 \%$ with the SMA $12 / 60$, and $4 \%$ with the SMA II. The variation in each case is within the limits of the method's reproducibility. The correlation coefficients between $A$ bell's method and the automated enzymic methods were 0.91 and 0.97 . The dispersion of the results was greater with the SMA 12/60 than with the chemical method, the respective standard deviations being 2.68 and $2.33 \mathrm{mmol} / \mathrm{l}$. In the case of freeze-dried commercial sera, the results obtained with the chemical and the enzymic methods agreed (tab. 6).

Tab. 4. Reproducibility of cholesterol assays on three automated analyzers (Results are expressed in mmol/l).

\begin{tabular}{|c|c|c|c|c|c|c|c|}
\hline & \multicolumn{3}{|c|}{ GSA II Greiner } & \multicolumn{3}{|c|}{ SMA $12 / 60$ Technicon } & \multirow{2}{*}{$\begin{array}{l}\text { SMA II } \\
\text { Technicon } \\
\text { July }\end{array}$} \\
\hline & Marçh & April & May & March & April & May & \\
\hline Number & 43 & 25 & 47 & 217 & 180 & 197 & 214 \\
\hline Mean & 3.31 & 3.31 & 3.13 & 3.33 & 3.26 & 3.26 & 3.74 \\
\hline Standard deviation & 0.08 & 0.18 & 0.21 & 0.30 & 0.18 & 0.15 & 0.18 \\
\hline Coefficient of variation \% & 2.3 & 5.5 & 6.6 & 9 & 5.5 & 4.6 & 4.9 \\
\hline
\end{tabular}

Tab. 5. Accuracy of cholesțerol assay in fresh human plasma by chemical and automated enzymic methods (Results are expressed in mmol/1).

\begin{tabular}{|c|c|c|c|c|c|}
\hline & $\begin{array}{l}\text { Number of } \\
\text { determinations }\end{array}$ & $\begin{array}{l}\text { Mean (m) } \\
\text { Standard } \\
\text { deviation (s) }\end{array}$ & $\begin{array}{l}\text { Correlation } \\
\text { coefficient }\end{array}$ & Regression curve & $\begin{array}{l}\text { Difference } \\
\text { between enzymic } \\
\text { method and } \\
\text { Abell's method }\end{array}$ \\
\hline $\begin{array}{l}\text { Abell's method }\left(x_{1}\right) \\
\text { Enzymic method } \\
\text { GSA II Greiner }\left(y_{1}\right)\end{array}$ & $N=35$ & $\begin{array}{l}\mathrm{m}=5.84 \\
s=2.43 \\
m=6.03 \\
s=2.46\end{array}$ & 0.97 & $y_{1}=0.98 x_{1}+0.31$ & $+3.2 \%$ \\
\hline $\begin{array}{l}\text { A.bell's method }\left(\mathrm{x}_{2}\right) \\
\text { Enzymic method } \\
\text { SMA } 12 / 60\left(\mathrm{y}_{2}\right)\end{array}$ & $N=44$ & $\begin{array}{l}m=5.68 \\
s=2.33 \\
m=6.05 \\
s=2.68\end{array}$ & 0.95 & $y_{2}=1.18 x_{2}+0.18$ & $+6.5 \%$ \\
\hline $\begin{array}{l}\text { Abell's method }\left(\mathrm{x}_{3}\right) \\
\text { Enzymic method } \\
\text { SMA II }\left(\mathrm{y}_{3}\right)\end{array}$ & $\mathbf{N}=40$ & $\begin{array}{l}m=5.75 \\
s=1.11 \\
m=5.51 \\
s=1.04\end{array}$ & 0.91 & $y_{3}=0.86 x_{3}+0.57$ & $+4.7 \%$ \\
\hline
\end{tabular}


Tab. 6. Accuracy: Quality control within the laboratory (Results are expressed in $\mathrm{mmol} / \mathrm{l}$ ).

\begin{tabular}{lllll}
\hline $\begin{array}{l}\text { Abelr's } \\
\text { method }\end{array}$ & Enzymic method & \\
& & GSA II & SMA & SMA II \\
& Greiner & $12 / 60$ & Techni- \\
& & & Techni- & con \\
& & & \\
& & & con & \\
\hline
\end{tabular}

Serum 1

\begin{tabular}{lrrrr} 
Number of samples & \multicolumn{1}{c}{23} & \multicolumn{1}{c}{81} & \multicolumn{1}{c}{209} & - \\
Mean & 3.28 & 3.40 & 3.19 & - \\
Standard deviation & 0.23 & 0.15 & $0.14=$
\end{tabular}

Serum 2

\begin{tabular}{lrrll} 
Number of samples & 11 & 14 & - & 6 \\
Mean & 3.66 & 3.79 & - & 3.67 \\
Standard deviation & 0.24 & 0.13 & - & - \\
\hline
\end{tabular}

Munster et al. (15) also found that $A$ bell's method and the enzymic method gave the same results.

\section{Interlaboratory control}

Abell's method remains the method of choice for cholesterol assay used by the two groups who specialize in quality control in lipid assays, the World Health Organization (WHO, Lipid Reference Center for Europe, Dr. Grafnetter, Prague) and the Center for Disease Control (CDC, Lipid Research Clinic Laboratories, Atlanta).

Our results obtained by means of the enzymic method adapted to the GSA II were within the $5 \%$ limits set by the two control centers (tab. 7).

Tab. 7. Accuracy and precision: interlaboratory quality control (Results are expressed in $\mathrm{mmol} / \mathrm{l}$ ).

\begin{tabular}{lllll}
\hline & Accuracy & & Precision \\
& $\begin{array}{l}\text { Acceptable } \\
\text { mean } \\
\mathrm{m} \pm 5 \%\end{array}$ & $\begin{array}{l}\text { Mean } \\
\text { found } \\
\mathrm{n}=7\end{array}$ & $\begin{array}{l}\text { Acceptable } \\
\text { standard } \\
\text { deviation }\end{array}$ & $\begin{array}{l}\text { Standard } \\
\text { deviation } \\
\text { found }\end{array}$ \\
\hline $\begin{array}{l}\text { WHO } \\
\text { sera }\end{array}$ & & & & \\
1 & $3.28 \pm 0.16$ & 3.44 & 0.18 & 0.09 \\
2 & $8.61 \pm 0.43$ & 8.86 & 0.23 & 0.10 \\
CDC & & & & \\
sera & & & & \\
1 & $3.23 \pm 0.18$ & 3.36 & 0.18 & 0.11 \\
2 & $6.95 \pm 0.33$ & 6.95 & 0.21 & 0.28 \\
3 & $8.29 \pm 0.41$ & 8.50 & 0.23 & 0.14 \\
\hline
\end{tabular}

The specificity of the enzymic method depends upon that of the cholesterol oxidase $(16,17)$ extracted from Nocardia erythropolis. This enzyme has a wide spectrum: it also partially oxidises $\Delta 7$-cholestanol $(15,16$, $17,18)$, and fully oxidises cholestanol and 7-dehydrocholesterol (15). In human plasma these structural analogues of cholesterol are present at an average level of $0.05 \mathrm{mmol} / 1(20 \mathrm{mg} / \mathrm{l})$ for $\Delta 7$-cholestanol,
$0.10 \mathrm{mmol} / 1(40 \mathrm{mg} / \mathrm{l})$ for cholestanol, and $0.52 \mathrm{mmol} / 1$ $(200 \mathrm{mg} / \mathrm{l})$ for 7 -dehydrocholesterol. Therefore, the values found for an actual cholesterol level of $5.17 \mathrm{mmol} / \mathrm{l}(2 \mathrm{~g} / \mathrm{l})$ reached $5.94 \mathrm{mmol} / 1(2.30 \mathrm{~g} / \mathrm{l})$ for both $A$ bell's and the enzymic method.

Furthermore, the kinetics of hydrolysis by cholesterolesterase varies with the ester used (15). Cholesterol acetate, which is put into certain commercial sera, is hydrolyzed slowly; when such sera are analyzed by Abell's method, the results are $30 \%$ higher than those obtained by enzymic assay (19.20). Therefore, some of the commercial freeze-dried sera are apparently not suitable for calibration or quality control of enzymic cholesterol assays $(21,22)$.

Both $A$ bell's and enzymic methods remain only selected procedures compared with gas-liquid chromatography, which is becoming the reference method. Some studies have already demonstrated its greater specificity. Among the numerous derivatives of cholesterol, only cholestanol has the same retention time as cholesterol, and it is therefore the only plasma constituent that interferes in this method (15-23).

\section{Specificity}

The possible interferences were tested by treating a pool of plasma with drugs and bilirubin in solution, each assay being paralleled with an untreated reference sample. The results in table 8 are the means of three measurements made on treated and control plasma samples with the Greiner GSA II: none of the substances tested interfered with the enzymic assay.

Tab. 8. Effect of several drugs and of bilirubin on the enzymic assay of cholesterol on the Greiner GSA II.

\begin{tabular}{lcl}
\hline & $\begin{array}{l}\text { Concentration } \\
\text { in treated } \\
\text { plasma } \\
\text { (mmol/l) }\end{array}$ & $\begin{array}{l}\text { Variation } \\
\text { compared } \\
\text { with control }\end{array}$ \\
& 0.11 & -1.4 \\
\hline Ascorbic acid & 1.1 & -0.3 \\
Acetyl salicylic acid & 12 & +0.5 \\
Clofibrate & 1 & +1.2 \\
Procetofen & 2.3 & +0.9 \\
& 7.3 & +0.5 \\
Phenobarbital sodium & 0.8 & -2 \\
Bilirubin & 34 & +1.1 \\
& 85 & -4.3 \\
& 171 & -0.5 \\
\hline
\end{tabular}

Borner et al. (12) reported a negative interference of high concentrations (above $0.30 \mathrm{mmol} / \mathrm{l}$ ) of ascorbic acid on the enzymic assay of cholesterol, with $1 \mathrm{mmol} / \mathrm{l}$ of ascorbic acid inducing an underestimation of cholesterol of $0.84 \mathrm{mmol} / \mathrm{l}$. The following substances do not interfere with the assay: novalgine (12), salicylates, nicotinic acid, phenobarbital (24), steroid drugs, and hemoglobin (7); nor, even at concentrations ten times higher than physiological, do uric acid, 
creatinine, urea, and glucose $(2,3)$. However, bilirubin influences enzymic assays because it absorbs at the wavelength used in the colorimetric reaction, and it reacts with hydrogen peroxide to yield biliverdin. Its presence in large amounts causes a major underestimation of cholesterol (19). On the GSA II, this error is avoided by assaying a serum blank (12).

\section{Results in serum and plasma}

We have recently demonstrated that there is no significant difference between the concentration of cholesterol in serum and that in heparinized plasma (25). EDTA, however, has a diluting effect and thereby causes an osmotic redistribution of water between the cells and plasma; in its presence, the concentration of the cholesterol is lower than in serum (26).

\section{Storage}

We assessed the effect of the method of storage on the cholesterol concentration. Three pools of fresh plasma containing various concentrations of cholesterol were stored at $4{ }^{\circ} \mathrm{C}$ for 5 days and were assayed three times a day; the variations in the cholesterol concentration were within the analytical limits and were not statistically significant (tab. 9). With frozen plasma, our studies showed that the cholesterol concentration was stable for a year both at $-30^{\circ} \mathrm{C}$ and $-196^{\circ} \mathrm{C}$, as well as after freeze-drying (27).
Tab. 9. Sera stored five days at $4{ }^{\circ} \mathrm{C}$. Analysis of variance (F test) of cholesterol assay results on GSA II Greiner (Results are expressed in $\mathrm{mmol} / \mathrm{l}$ ).

\begin{tabular}{|c|c|c|c|c|c|c|}
\hline \multirow[t]{2}{*}{ Day } & \multicolumn{2}{|c|}{ Pool 1} & \multicolumn{2}{|c|}{ Pool 2} & \multicolumn{2}{|c|}{ Pool 3} \\
\hline & Mean & Variance & Mean & Variance & Mean & Variance \\
\hline $\begin{array}{l}1 \\
2 \\
3 \\
4 \\
5\end{array}$ & $\begin{array}{l}3.04 \\
3.16 \\
3.16 \\
3.19 \\
3.20\end{array}$ & $\begin{array}{l}0.0025 \\
0.0046 \\
0.0025 \\
0.0003 \\
0.0006\end{array}$ & $\begin{array}{l}5.59 \\
5.58 \\
5.73 \\
5.80 \\
5.73\end{array}$ & $\begin{array}{l}0.0010 \\
0.0121 \\
0.0146 \\
0.0170 \\
0.0006\end{array}$ & $\begin{array}{l}7.67 \\
7.72 \\
7.70 \\
7.88 \\
7.80\end{array}$ & $\begin{array}{l}0.0001 \\
0.0320 \\
0.0085 \\
0.0034 \\
0.0041\end{array}$ \\
\hline $\begin{array}{l}\mathrm{F} \\
\text { Test }\end{array}$ & 3.90 & ns & 2.34 & ns & 1.51 & ns \\
\hline
\end{tabular}

\section{Conclusion}

We have compared the results from Allain's method of enzymic cholesterol assay adapted to three different automated analyzers. The precisions were satisfactory, especially on the GSA II and SMA II. On the SMA $12 / 60$, the reaction time was too short to allow the plateau of the reaction to be reached. The results obtained by the three methods were similar to those obtained by Abell's selected method. However, the accuracy of the enzymic methods depends on the specificity of both the cholesterol esterase and the cholesterol oxidase. We found no interference from the addition of certain drugs or of bilirubin.

\section{Acknowledgments}

This work was supported by contract INSERM, CRL 77-1-192-8.

\section{References}

1. Fruchart, J.-C. (1976), In Lipides et lipoprotéines, Crouan \& Roques Ed., Lille, 50-139.

2. Allain, C. C., Poon, L. S., Chan, C. S. G., Richmond, W. \& Fu, P. C. (1974), Clin. Chem. 20, 470=475.

3. Lie, R. F., Schmitt, J. M., Pierre, K. J. \& Gochman, N. (1976), Clin. Chem. 22, 1627-1630.

4. Klose, S., Hagen, A. \& Greif, A. (1975), In 3e Colloque International de Biologie Prospective, l'Expansion Scientifique Ed., Pont-à-Moussoñ, 505-507.

5. Trocha, P. J. (1977), Clin. Chem. 23, 146-147.

6. Pesce, M. A. \& Bodourian, S. H. (1977), Clin. Chem. 23, 280-282.

7. Witte, D. L., Barett, D. A. \& Wycoff, D. A. (1974), Clin. Chem. 20, 1282-1286.

8. Wentz, P. W., Cross, R. E. \& Savory, J. (1976), Clin. Chem. $22,188=192$.

9. Zoppi, F. \& Fenili, D. (1976), Clin. Chem. 22, 690-691.

1.0. Nobbs, B. T., Smith, T. H. \& Walker, A. W. (1977), Clin. Chim. Acta 79, 391-397.

11. Seymour, G. C. \& Gray, C. J. (1978), Medical Laboratory Sciences 35, 55-61.

12. Borner, K. \& Klose, S. (1977), J. Clin. Chem. Clin. Biochem. 15, 121-130.

13. Abell, L. L., Levy, B. B., Brodie, B. B. \& Kendall, F. C. (1952), J. Biol. Chem. 195, 357-366.
14. Van Gent, C. M., Van der Voort, H. A., De Bruyn, A. M. \& Klein, F. (1977), Clin. Chim. Acta 75, 243-251.

15. Munster, D. J., Lever, M. \& Carrell, R. W. (1976), Clin. Chim. Acta 68, 167-175.

16. Richmond, W. (1973), Clin. Chem. 19, 1350-1356.

17. Richmond, W. (1976), Clin. Chem. 22, 1570-1588.

18. Peynet, J., Canal, J., Delattre, J., Rousselet, F. \& Girard, M. L. (1976), Ann. Biol. Clin. 34, 19-26.

19. Zak, B. (1977), Clin. Chem. 23, 1201-1214.

20. Żak, B. (1977), Clin. Chem. 23, 1940.

21. Hunter, L. L. \& Grady, H. J. (1977), Clin. Chem. 23, 1945-1946.

22. Caragher, T. E. \& Newman, H. A. I. (1976), Clin. Chem. 22, 1193.

23. Watts, R., Carter, T. \& Taylor, S. (1976), Clin. Chem. 22, 1692-1696.

24. Pesce, M. A. \& Bodourian, S. H. (1977), Clin. Chem. 23, 757-760.

25. Henny, J., Houot, O., Steinmetz, J. \& Siest, G. (1976), Ann. Biol. Clin. 34, 335-340.

26. Laboratory Methods Committee of the Lipid Research Clinics Programs of the National Heart, Lung and Blood Institute Bethesda Md 20014 (1977), Clin. Chem. 23, $60-63$.

27. Henny, J. (1976), Thèse de Doctorat d'Etat, Faculté des Sciences Pharmaceutiques et Biologiques, Nancy.

\author{
J. Steinmetz \\ Laboratoire du \\ Centre de Médecine Préventive \\ 2, avenue du Doyen Jacques Parisot \\ F-54500 Vandoeuvre-Les-Nancy, France
}




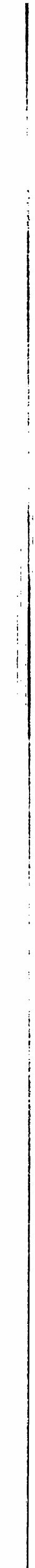

